\title{
EHEALTH LITERACY, INTERNET AND EHEALTH SERVICE USAGE: A SURVEY AMONG CANCER PATIENTS AND THEIR RELATIVES
}

\author{
Dissertation \\ zur Erlangung des akademischen Grades \\ doctor medicinae (Dr. med.) \\ vorgelegt dem Rat der Medizinischen Fakultät \\ der Friedrich-Schiller-Universität Jena
}

von Nikolaus Halwas

geboren am 12. November 1990 in Eichstätt 


\section{Gutachter}

1. Prof. Dr. Jutta Hübner, Jena

2. apl. Prof. Dr. Michael Hartmann, Jena

3. Prof. Dr. Horst Christian Vollmar, Bochum

Tag der öffentlichen Verteidigung: 03.12.2018 


\section{Inhaltsverzeichnis}

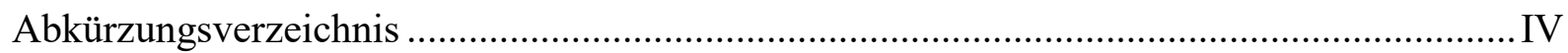

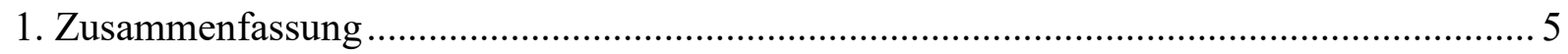

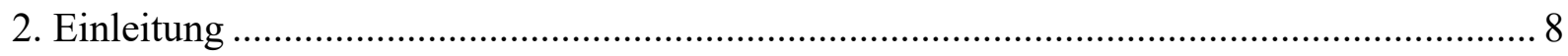

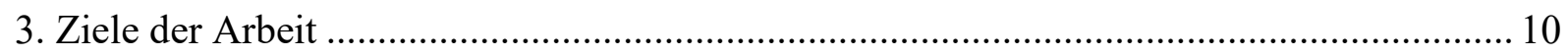

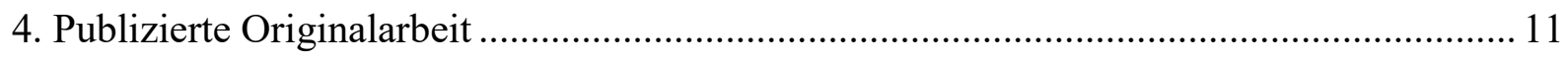

eHealth literacy, Internet and eHealth service usage: a survey among cancer patients and their relatives; Nikolaus Halwas, Lena Griebel, Jutta Hübner; J Cancer Res Clin Oncol. 2017 Nov; 143(11) : 2291 - 2299. doi: 10.1007/s00432-017-2475-6. Epub 2017 Jul 11 .... 11

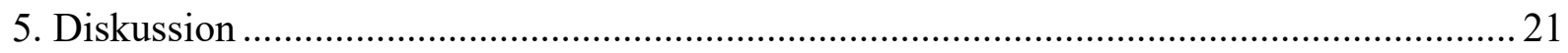

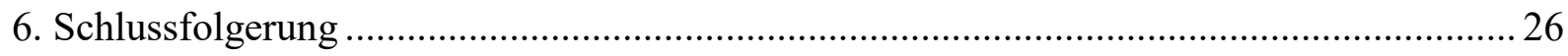

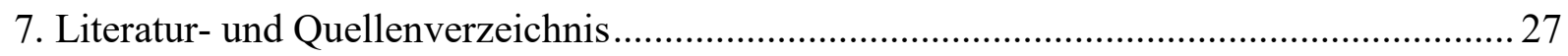

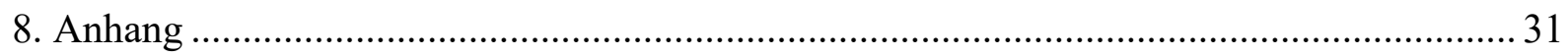

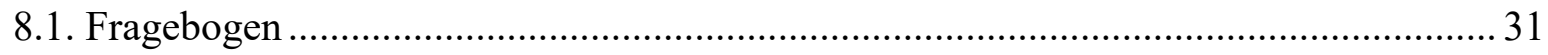

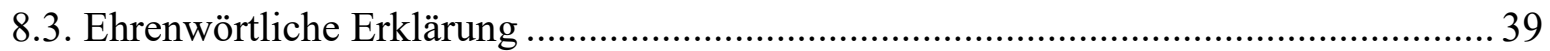

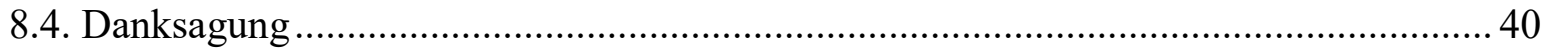




\section{Abkürzungsverzeichnis}

$\begin{array}{ll}\text { ANOVA } & \text { Analysis of Variance } \\ \text { CHESS } & \text { Comprehensive Health Enhancement Support System } \\ \text { eHEALS } & \text { eHealth Literacy Scale } \\ \text { HLS-EU-47 } & \text { European Health Literacy Survey } \\ \text { PERQ } & \text { Patient eHealth Readiness Questionnaire } \\ \text { REALM } & \text { Rapid Estimate of Adult Literacy in Medicine } \\ \text { SILS } & \text { Single Item Literacy Screener } \\ \text { TOFHLA } & \text { Test of Functional Health Literacy in Adults } \\ \text { WRAT } & \text { Wide Range Achievement Test }\end{array}$




\section{Zusammenfassung}

An Krebs erkrankte Patienten und deren Angehörige haben einen erhöhten Informationsbedarf hinsichtlich der Erkrankung (Protiere et al. 2012). Der behandelnde Arzt stellt bisher die meist genutzte Informations- und Aufklärungsquelle zum Krankheitsgeschehen dar. Der zeitlich begrenzte Rahmen der medizinischen Konsultation limitiert jedoch den Umfang der krankheitsbezogenen Wissensvermittlung. Mit zunehmender Digitalisierung wird nun auch das Internet als ein einfacher und weit verbreiteter Zugang zu einer großen Brandbreite an vielversprechenden Informationsquellen von den Betroffenen angesehen. Die unbegrenzte Anzahl an eHealth Angeboten ist von unterschiedlicher Qualität. Daher ist es für die Betroffenen eine Herausforderung die Informationsflut zu bewältigen und zu beurteilen. Die Fähigkeit der Patienten Gesundheitsinformationen aus elektronischen Quellen zu suchen, zu finden, zu verstehen, zu bewerten und auf die Erkrankung oder Fragestellung anzuwenden, wird als eHealth Literacy bezeichnet (Norman and Skinner 2006b). Das Leseverständnis spielt hierbei eine Schlüsselrolle, sodass zahlreiche Testinstrumente, wie etwa TOFHLA (Test of Functional Health Literacy in Adults), REALM (Rapid Estimate of Adult Literacy in Medicine) und SILS (Single Item Literacy Screener), entwickelt wurden, um das Leseverständnis im medizinischen Kontext zu messen.

In der Literatur werden bei Patienten inadäquate Health Literacy Levels von $23 \%$ (Morris et al. 2006) bis zu 46 \% (Paasche-Orlow et al. 2005) beschrieben. Im Rahmen des HLS-EU-47 (European Health Literacy Survey) wurde das Health Literacy Level in acht europäischen Ländern erhoben. Deutschland lag mit einem Punktwert von 31,9 unterhalb des Durchschnittwertes von 33,8 (Zok 2/2014). Eine adäquate eHealth Literacy ermöglicht den Patienten vertrauenswürdige Gesundheitsinformationen von unseriösen Angeboten aus dem Internet zu differenzieren.

Ziel dieser Arbeit war es das allgemeine Internetnutzungsverhalten, die Nutzung von eHealth Angeboten sowie eHealth Literacy bei Krebspatienten und deren Angehörigen zu untersuchen und zu analysieren.

Die Daten wurden anhand eines standardisierten Fragebogens erhoben. Hierfür wurden unter anderem Fragebögen wie PERQ (Patient eHealth Readiness Questionnaire) und eHEALS (eHealth Literacy scale) herangezogen und durch weitere Items modifiziert (Jones 2013, Norman and Skinner 2006a). 
Im Rahmen eines Pilotverfahrens wurde ein Fragebogen entwickelt, der an 19 Probanden getestet und entsprechend optimiert wurde. An der Studie selbst nahmen 142 Teilnehmer teil. Bei Vorträgen zur Komplementär- und Alternativmedizin, die durch regionale Krebsgesellschaften organisiert wurden, hatten die Teilnehmer im Anschluss eines jeden Vortrags die Möglichkeit den Fragebogen auszufüllen. Der Fragebogen bestand aus sieben Teilbereichen: 1. Demographische Daten, 2. Generelles Internetnutzungsverhalten, 3. Nutzung von eHealth Angeboten, 4. eHealth Literacy, 5. SILS, 6. Häufigkeit der Nutzung von Gesundheitsinformationsquellen und 7. Zufriedenheit mit dem Vortrag. Der Fragebogen enthielt geschlossene Fragestellungen mit einer Auswahl an Antwortmöglichkeiten. Bei den eHealth Literacy Items wurden acht Aussagesätze formuliert, die die Teilnehmer anhand von Likert Skalen ( 1 = „Ich stimme überhaupt nicht $\mathrm{zu}^{\text {“ }}$ bis $10=$ „Ich stimme voll und ganz $\left.\mathrm{zu}^{\text {“ }}\right)$ bewertet haben. Für die eHealth Literacy Items wurde eine innere Konsistenz von Cronbach alpha 0,851 berechnet. Des Weiteren wurde ein Ethikvotum vom Ethikkomitee des Universitätsklinikums der Friedrich-Schiller-Universität Jena eingeholt (Nummer: 515305/17). Für die Erhebung und Analyse der Daten wurde IBM SPSS Statistics 24 benutzt. Die Häufigkeiten und Assoziationen wurden mittels Chi-Quadrat-Test und ANOVA (Analysis of Variance) berechnet und $\mathrm{p}<0,05$ als statistisch signifikant gewertet. Die Ergebnisse der Befragung zeigten, dass das Internet eine wichtige Informationsquelle darstellt und von 50,4 $\%$ der Befragten täglich genutzt wird.

In diesem Zusammenhang wurden folgende Ergebnisse eruiert: Je jünger die Teilnehmer und je besser die Internetverbindung, desto häufiger wurde das Internet genutzt. Je jünger die Teilnehmer und je höher das Bildungsniveau, desto besser wurden die eHealth Angebote verstanden. Weiterhin konnten jüngere Probanden und jene, die eHealth Angebote regelmäßig nutzten, Gesundheitsangebote aus dem Internet besser für ihre Entscheidungsfindung heranziehen. Jüngere Teilnehmer konnten zuverlässige von unzuverlässigen Gesundheitsinformationen aus dem Internet besser trennen und sich medizinisches Wissen, vermittelt durch eHealth Angebote, besser aneignen. Bei der Suche nach Gesundheits-Apps waren jüngere Probanden versierter. Annähernd ein Drittel der Teilnehmer wies ein eingeschränktes medizinisches Leseverständnis auf. Probanden mit angemessenem Leseverständnis konnten eHealth Angebote auch besser erfassen. Die eHealth Literacy Items mit den am niedrigsten erhobenen Durchschnittswerten waren: „Ich fühle mich sicher, Gesundheitsentscheidungen auf der Basis von eHealth Angeboten zu treffen“ und „Bei der Nutzung von Gesundheitsinformationen aus dem Internet weiß ich sicher, ob diese aus zuverlässigen oder unzuverlässigen Quellen stammen“. Dies verdeutlichte das geringe 
Vertrauen der Teilnehmer in die eHealth Literacy Ressourcen und die herabgesetzte Fähigkeit das Internet als Informationsquelle im Hinblick auf eigene Gesundheitsbedürfnisse heranzuziehen.

Weitere Nachforschungen sind erforderlich, um das Informationsbedürfnis der Patienten und deren Nutzung von eHealth Angeboten sowie deren eHealth Literacy Fähigkeiten zu untersuchen. 


\section{Einleitung}

Die Herausforderung des behandelnden Arztes ist es unter anderem dem besonders hohen Informationsbedürfnis von Krebspatienten und Patienten, die an chronischen Erkrankungen leiden, gerecht zu werden (Arora et al. 2008). Im klinischen Alltag hat dieser jedoch nur ein begrenztes Zeitfenster um die Patienten über die Erkrankung, die Diagnostik, die Therapie, die Prognose etc. aufzuklären und zu informieren.

Bei dem Behandlungskonzept „shared-decision-making“ integriert der Arzt den Patienten in den Therapieablauf. Durch gemeinsame Entscheidungsfindung wird die Autonomie des Patienten gestärkt. Die Vorteile dieses Konzeptes liegen in einer erhöhten Therapieadhärenz, einer verbesserten Compliance sowie einer erhöhten Patientenzufriedenheit. Das Behandlungskonzept setzt jedoch voraus, dass die Patienten ausreichend über ihre Erkrankung informiert sind. Dies setzt die Fähigkeit der Patienten, Gesundheitsinformationen zu suchen, zu finden, zu verstehen und auf deren Situation hin anzuwenden, voraus und wird als Health Literacy bezeichnet. Der Begriff wurde erstmals 1974 angewandt (Simonds). Ein konzeptionelles Modell beschreibt Health Literacy als Zusammenspiel zwischen der Grundbildung (Lesen, Schreiben, Rechnen, Sprachverständnis), den individuellen Ressourcen und den Gesundheitsinformationen (Institute of Medicine Committee on Health, 2004).

Im deutschsprachigen Raum ist das Konzept Health Literacy als Gesundheitskompetenz bekannt. Um den Grad der Health Literacy zu messen, wurde im Rahmen des HLS-EU-47 ein validierter Fragebogen in acht europäischen Ländern angewandt. Deutschland erreichte dabei einen Punktewert von 31,9, der unterhalb des Durchschnittwertes von 33,8 lag. Im Ergebnis wiesen $45 \%$ der deutschen Teilnehmer eine problematische und 15,5\% eine unzureichende Gesundheitskompetenz auf (Zok 2/2014).

Eine unzureichende Health Literacy hat weitreichende Folgen. Assoziiert wird dies mit geringer psychosozialer Gesundheit und gesteigerter Angst (Halbach et al. 2016). Darüber hinaus mit verminderter Inanspruchnahme präventiver Maßnahmen, höherer Hospitalisierungsrate und damit einhergehend mit steigenden Kosten für das Gesundheitssystem (Collins et al. 2012), verbunden mit geringer Therapieadhärenz und ungenügendem Wissen über die Erkrankung (Sorensen et al. 2012). Im Rahmen der Digitalisierung bietet das Internet ein gewaltiges Potential für den Wissenserwerb, sodass der Begriff auf eHealth Literacy erweitert wurde. Hiermit werden nun vor allem das Suchen, Finden, Verstehen und Anwenden von Gesundheitsinformationen aus elektronischen Informationsquellen erfasst. Durch die Verwendung von Computern und anderen 
elektronischen Geräten, wie Smartphone und Tablet-Computer wird der Zugang zu einer großen Menge an Gesundheitsinformationen erleichtert. Diese bestehen teilweise aus ungeprüften und unseriösen Inhalten, falschen Gesundheitsinformationen und verkaufsorientierten Produktvermarktungen. Dies stellt eine besondere Herausforderung dar, qualitativ hochwertige von unzuverlässigen Webseiten zu unterscheiden (Barnes et al. 2003; Feufel and Stahl 2012; Gustafson et al. 2008; Wasserman et al. 2014).

Gerade im Bereich der Alternativ- und Komplementärmedizin, die 50 \% der Krebspatienten in Anspruch nehmen, gibt es eine kaum überschaubare Anzahl an unseriösen Angeboten im Internet, die Krebspatienten Heilung und nebenwirkungsarme bis -freie Therapien in Aussicht stellen. Die mindere Qualität der Informationsquellen kann zu Misstrauen in der ArztPatienten-Beziehung führen (Ebel et al. 2015). Ziele der integrativen Onkologie sind unter anderem, Patienten aufzubauen, zu aktivieren und evidenzbasierte Informationen zur Komplementär- und Alternativmedizin bereitzustellen. „Prävention und Integrative Onkologie“ eine Arbeitsgemeinschaft der Deutschen Krebsgesellschaft bietet Vorträge an, in denen evidenzbasierte Informationen Krebspatienten und deren Angehörigen zur Verfügung gestellt werden, um deren eHealth Literacy zu fördern. In diesem Zusammenhang hatten die Zuhörer die Möglichkeit an der Studie der Dissertation teilzunehmen. 


\section{Ziele der Arbeit}

Ziel der vorliegenden Arbeit war es, erstmals bei Patienten mit einer Krebserkrankung in Deutschland, Daten zur Nutzung von eHealth Angeboten und eHealth Literacy zu gewinnen.

Dies bildet die Grundlage, um Patienten zukünftig besser mit Gesundheitsinformationen aus dem Internet versorgen zu können. Weiterhin ermöglicht es, Patienten zu aktivieren und zu motivieren und dadurch die Therapieadhärenz zu verbessern und das Therapieergebnis positiv zu beeinflussen. 


\section{Publizierte Originalarbeit}

eHealth literacy, Internet and eHealth service usage: a survey among cancer patients and their relatives; Nikolaus Halwas, Lena Griebel, Jutta Hübner; J Cancer Res Clin Oncol. 2017 Nov; 143(11) : 2291 - 2299. doi: 10.1007/s00432-017-2475-6. Epub 2017 Jul 11 


\title{
eHealth literacy, Internet and eHealth service usage: a survey among cancer patients and their relatives
}

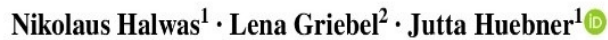

Received: 23 June 2017 / Accepted: 6 July 2017 / Published online: 11 July 2017

(c) Springer-Verlag GmbH Germany 2017

\begin{abstract}
Purpose The aim of our study was to investigate Internet and eHealth usage, with respect to eHealth literacy, by cancer patients and their relatives.

Patients and methods Using a standardized questionnaire we asked patients who attended lectures on complementary medicine in 2016.

Results We received 142 questionnaires. The frequency of general Internet usage was directly associated with younger age and better Internet connection. Younger participants were not only more confident in allocating healthrelated Internet information into reliable or unreliable facts, but also more confident and capable of gaining medical knowledge through eHealth services. A regular use of eHealth services facilitated the decision-making process. Reading ability was associated with a better understanding regarding eHealth offers.

Conclusion In a modern health care system, emphasis should be on skills contributing to eHealth literacy among patients to improve their ability to profit from eHealth offers and improve health care.
\end{abstract}

\footnotetext{
$\triangle$ Jutta Huebner

jutta.huebner@med.uni-jena.de

Nikolaus Halwas

nikolaus.halwas@uni-jena.de

Lena Gricbel

lena.griebel@fau.de

I Medizinische Klinik II, Hämatologie und Internistische Onkologie, Universitätsklinikum Jena, Am Klinikum 1, 07747 Jena, Germany

2 Chair of Medical Informatics, Friedrich-Alexander-University Erlangen-Nürnberg, Erlangen, Germany
}

Keywords eHealth literacy · eHealth service - Internet · Cancer $\cdot$ Patient information

\section{Introduction}

Cancer patients have an increased demand for health information on their disease (Protiere et al. 2012). The acquisition of health information is an extensive process that depends on several internal and external factors. Medical consultation is the most utilized source to achieve health information about medical condition (Keinki et al. 2016). Due to time restrictions of the medical staff it is difficult to response to all requirements of particularly cancer patients. Another limiting factor is the various level of health literacy among cancer patients making it complicated to provide health information to the right extent and in the right form. "Health literacy" is a short but complex term with a manifold meaning and defined in several ways (Friedman and Hoffman-Goetz 2008; Sorensen et al. 2012). It was firstly described by Simonds (Simonds 1974). In the report of Healthy People 2010 by the U.S. Department of Health and Human Services the following definition of health literacy was used: "The degree to which individuals have the capacity to obtain, process, and understand basic health information and services needed to make appropriate health decisions" (Ratzan and Parker 2000; Sevices 2000). A conceptual framework described health literacy as the connector between literacy skills (containing reading, writing, basic mathematics, speech and speech comprehension skills) and individual abilities and health-related information (Institute of Medicine Committee on Health, 2004). The concept of health literacy is promoted by the European Union since. A validated instrument for measuring health literacy is the HLS-EU-47, a questionnaire 
which was applied on EU-citizens in eight European countries. Germans insured by the statutory health care system reached an average health literacy score of 31.9. That score was below the index value of 33.8 which was reported in the European Health Literacy Survey. Forty-five percent of the participants had a knowledge level which was rated as problematic and for another $14.5 \%$ it was rated as inadequate (Zok 2/2014). These numbers are also consistent with the results of an analysis of elderly women newly diagnosed with breast cancer where about half of the patients were classified as having limited health literacy (Halbach et al. 2016). Inadequate health literacy is associated with poorer psychosocial health and increased anxiety (Halbach et al. 2016), lower use of preventive services, higher rates of emergency department utilization, greater risk of hospitalization, increasing costs for the health care system (Collins et al. 2012; Sevices 2000), decreased medication adherence and knowledge of disease (Sorensen et al. 2012). The Internet as a potential source of gaining health information takes an important role (Warren et al. 2014). In the era of computer and smartphone technology associated with the advantage of global accessibility (Richards et al. 1998; Wasserman et al. 2014) the Internet reduces barriers to accessing health information (Arora et al. 2008). The concept of shared decision-making that is applied especially for cancer and chronic disease expects the patient to be well informed about diagnosis, symptoms, treatment and sequelae (Arora et al. 2008). Therefore, a vast amount of variable eHealth interventions was developed for providing health care information and support. Usually they are based on computer or other electronic devices (smartphone, tablet) and delivered through the Internet (Ventura et al. 2013). Several computer-based health communication systems like CHESS showed favorable results (Gustafson et al. 2008). Even though the Internet provides a great potential for accessible health care information it also carries critical risks. Within the chaos of inconstant information, it can be very difficult to identify health information of high quality from the Internet and to discern which resources are reliable or appropriate. Many websites are biased due to selfpromotion, advertisements, and are commercial. In addition, claims without evidence, uncontrolled chat rooms and blogs complicate the information-seeking process (Barnes et al. 2003; Feufel and Stahl 2012; Gustafson et al. 2008; Wasserman et al. 2014). The quality of information is heterogeneous and false information may lead to distrust in the practitioner or wrong decision-making (Ebel et al. 2015). In consideration of the lack of knowledge about Internet usage behavior of German cancer patients our questionnaire aimed to generate data on their attitudes towards and dealing with eHealth offers to improve providing health information. Considering the vast amount of electronic health sources for cancer patients and the importance to use such information in the light of shared decision making, eHealth literacy of cancer patients was another focus of this study. eHealth literacy is defined as: "The ability to seek, find, understand, and appraise health information from electronic sources and apply the knowledge gained to addressing or solving a health problem" (Norman and Skinner 2006b).

\section{Methods and patients}

The questionnaire was derived from the first version of a questionnaire on information needs of cancer patients and the Internet (Ebel et al. 2015). We modified and added questions regarding eHealth interventions and eHealth literacy investigations. Furthermore, we used the Patient eHealth Readiness Questionnaire (PERQ) as a basis for measure the eHealth use behavior of patients (Jones 2013). Other items on eHealth literacy were developed by the researchers. For this we took literature on technology, acceptance and eHealth literacy into account and used existing questionnaires such as the eHealth literacy scale (eHEALS) by Norman and Skinner as a basis and enriched it by other items that we regarded relevant for our purpose (Norman and Skinner 2006a). A pilot version of the questionnaire was developed and tested by 19 participants. The participants we surveyed were attending a series of standardized lectures on complementary and alternative medicine (CAM). The questionnaires were delivered to participants at the beginning of the lecture. These lectures were organized in cooperation with the regional cancer societies and are financially supported by the Techniker Krankenkasse, a public health insurance. The presenter explained the items of the questionnaire as well as the importance of the survey for the German Cancer Society at the beginning of the lectures. We asked the participants to hand back the questionnaires anonymously at the end of the lecture while leaving the room. The questionnaire consisted of seven parts:

1. Demographic data (six questions: status (patient before or after treatment, relative, or other), age, gender, diagnosis, year of initial diagnosis and education level).

2. Data on general Internet usage (three questions: concerning frequency and setting of Internet usage and quality of Internet connection).

3. Data on eHealth usage (two questions: concerning frequency and variable eHealth offers).

4. Data on eHealth literacy (eight items: concerning understanding, finding, secureness, usefulness, reliability and knowledge growth of health information provided through the Internet; finding and usage of smartphone/tablet Apps). 
5. Data on Single Item Literacy Screener (one question).

6. Data on frequency of using health information resources (one question).

7. Satisfaction with the lecture.

We used closed questions, providing a list of possible answers (e.g., how often did you use the internet in the last three months? daily; several times a week; several times a month; rarer; never). Concerning the eHealth literacy Items the questionnaire contains eight statements that were assessed by the participants using Likert scales (e.g., the understanding of health-related Internet offers I have already used was good: $1=\mathrm{I}$ totally disagree to $10=\mathrm{I}$ totally agree, including the possibility to choose "I have not used health related Internet offers yet"). According to the ethics committee at the University Hospital of the Friedrich Schiller University at Jena, an ethics vote was necessary (Number: 5153-05/17). IBM SPSS Statistics 24 was used for data collection and analysis of frequencies and associations were carried out using Chi-squares test and ANOVA; $p<0.05$ was considered significant. In this article, we present data on general internet usage, eHealth usage, eHealth literacy and Single Item Literacy Screener within German cancer patients.

\section{Results}

\section{Demographic data}

The questionnaire was delivered in six lectures to 256 participants. From those, $142(55.5 \%)$ participants returned the questionnaire (see Table 1). Among these, 108 (76.1\%) were patients under current or after treatment. The percentage of female participants was $64.1 \%$. Concerning age, the arithmetic mean value was 62 years. Only $16.2 \%$ of the participants were 50 years or younger. The most frequent tumor was breast cancer (35.2\%) followed by colorectal cancer $(7.7 \%)$ and prostate cancer $(7.0 \%)$. Majority of participants $(65.5 \%)$ had their initial cancer diagnosis 1-10 years ago. The education level was categorized in low, middle and high according to the German educational system: low education level contains no graduation, elementary school and general school degree; middle education level contains secondary modern school and technical diploma; high education level contains high school diploma and college degree.

\section{Data on general Internet usage}

Of 142 participants, $70(50.4 \%)$ stated that they use the Internet daily and $42(30.2 \%)$ several times a week, which was categorized in "frequent Internet usage". 7 (5.0\%)
Table 1 Demographic data

\begin{tabular}{|c|c|c|}
\hline Demographic data & Number of patients & $\%$ \\
\hline \multicolumn{3}{|l|}{ Status } \\
\hline Patient, current treatment & 63 & 44.4 \\
\hline Patient, after treatment & 45 & 31.7 \\
\hline Relatives & 20 & 14.1 \\
\hline Others & 14 & 9.9 \\
\hline \multicolumn{3}{|l|}{ Gender } \\
\hline Male & 34 & 23.9 \\
\hline Female & 91 & 64.1 \\
\hline No answer & 17 & 12.0 \\
\hline \multicolumn{3}{|l|}{ Age } \\
\hline$<51$ years & 23 & 16.2 \\
\hline $51-65$ years & 45 & 31.7 \\
\hline$>65$ years & 50 & 35.2 \\
\hline No answer & 24 & 16.9 \\
\hline \multicolumn{3}{|l|}{ Type of cancer } \\
\hline Breast cancer & 50 & 35.2 \\
\hline Gynecological cancers & 9 & 6.3 \\
\hline Prostate cancer & 10 & 7.0 \\
\hline Leukemia and lymphoma & 8 & 5.6 \\
\hline Colorectal cancer & 11 & 7.7 \\
\hline Other gastrointestinal cancers & 4 & 2.8 \\
\hline Lung cancer & 1 & 0.7 \\
\hline Melanoma & 3 & 2.1 \\
\hline No answer & 46 & 32.4 \\
\hline \multicolumn{3}{|l|}{ Year of initial diagnosis } \\
\hline$<1$ year & 13 & 9.2 \\
\hline $1-5$ years & 55 & 38.7 \\
\hline $6-10$ years & 38 & 26.8 \\
\hline$>10$ years & 9 & 6.3 \\
\hline No answer & 27 & 19.0 \\
\hline \multicolumn{3}{|l|}{ Level of education } \\
\hline Low & 34 & 23.9 \\
\hline Middle & 48 & 33.8 \\
\hline High & 56 & 39.4 \\
\hline Others & 4 & 2.8 \\
\hline
\end{tabular}

participants stated the Internet usage both several times a month and rarer. Of $13(9.4 \%)$ participants, who stated that they never use the Internet, 12 had no Internet access and 1 chose the option "I don't know". These were categorized as "poor Internet usage". There was no difference for general Internet usage in terms of gender. Nevertheless, there was a statistically significant difference regarding age $(p=0.001)$ : Among participants younger than 51 years old all and among 51-65 years old 91.1\% showed a "frequent Internet Usage". $62.5 \%$ of participants older than 65 years showed "frequent Internet usage" and therefore 37.5\% showed "poor Internet usage". 77.1\% stated that their Internet connection was fast enough and just $10 \%$ did not have 
Internet access. The frequency of general Internet usage depended on the quality of Internet connection ( $p=0.001)$. Participants possessing an Internet speed that was fast enough for their requirements were using the Internet more frequently than those possessing an Internet speed that was too slow. Most of the participants $(86.4 \%)$ were using the Internet through a computer at home and $16.8 \%$ at work. $44.8 \%$ through a mobile device and solely $5.6 \%$ were using the Internet through public access.

\section{Data on eHealth usage}

Of 142 participants, 126 answered the question about the frequency of using eHealth offers. A majority (55.6\%) of the attendees reported that they use them from time to time and just $10.3 \%$ regularly. We categorized this group as "frequent use". Participants who chose the options "I have already used them once" (14.3\%), "I would use them but I have not yet" $(12.7 \%)$ and "they are out of question for me" $(7.1 \%)$ were categorized as "rare use". Although there was no statistically significant difference for frequency of eHealth usage regarding gender $(p=0.468)$, we want to mention that $40.0 \%$ of the men and $56.4 \%$ of the women were using eHealth offers frequently. In respect to age groups, there was no statistically significant difference although the proportion of participants using eHealth offers under 51 years old was $82.6 \%, 51-65$ years old was $71.1 \%$ and over 65 years old was $56.8 \%(p=0.099)$ and showed a declining trend with rising age. Participants of the low level of education group were using eHealth offers with a proportion of $61.5 \%$ frequent. While the proportion of those of the high education level group was $72.2 \%$. Despite our expectations there was also no statistically significant difference $(p=0.442)$. We proposed to our participants a selection of eHealth services and asked them to indicate which they already used. $78.4 \%$ of participants have used the Internet for searching health information followed by $46.6 \%$ who were seeking medical terms in an online encyclopedia and $39.3 \%$ who were searching for medical specialists in the Internet. The latest eHealth innovations such as smartphone Apps, fitness trackers and eBooks were used quite rarely (see Fig. 1).

\section{Data on eHealth literacy}

The next items were gathered by a Likert scale from 1 (I totally disagree) to 10 (I totally agree) as it is already described in the methodic part. "The comprehension of health-related Internet offers, which participants have already used was good" was stated with 6.5 , where 10 means that the participants totally agreed to the statement. There was no difference in regard of comprehension of Internet offers regarding gender. We realized that

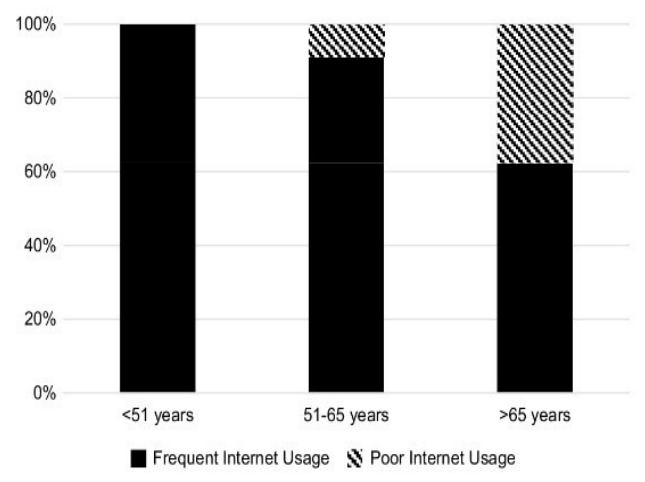

Fig. 1 Frequency of Internet usage and age

the older the participant was, the lower was the mean value of comprehension $(p=0.02)$. While the group under 50 years old reached an arithmetic mean value of 7.8 , the group between 51 and 65 years old yielded 6.33 and over 65 years old achieved $6.28(10=$ total agreement to the statement). Furthermore, the association between the level of education and comprehension of health-related Internet was statistically significant. While participants of low education level reached a mean value of 5.25 , those of high education level achieved 7.15 $(p=0.002)$.

With the next item we evaluated whether the participants know where they can find suitable health information for their requirements. The arithmetic mean value was 6.1. There were no differences in terms of gender, age or level of education. There was also no statistically significant association regarding the frequency of Internet usage, although we expected that participants using the Internet more frequently were more skilled in finding health information.

The item that explored the sense of feeling safe while making treatment decisions based on Internet information yielded a mean value of 4.64. Compared to the mean values of the other items it was very low (see Fig. 2). Neither gender nor age was associated with this item. It is interesting that participants of the low education level yielded a mean value of 5.56, of the middle education level 4.71 and of the high one 4.13 .

The next item examined the usefulness of health-related Internet offers that were already used by the participants for their decision-making process. The mean value was 4.82 and it is noteworthy that $12.5 \%$ saw no benefit from eHealth offers for their decision-making process. There was no association between this item and gender or level of education. Participants under 51 years (6.11) achieved a significant higher mean value than those between 51 and 65 years (4.11) and over 65 years $(4.64)(p=0.015)$. 
Fig. 2 Usage of eHealth services

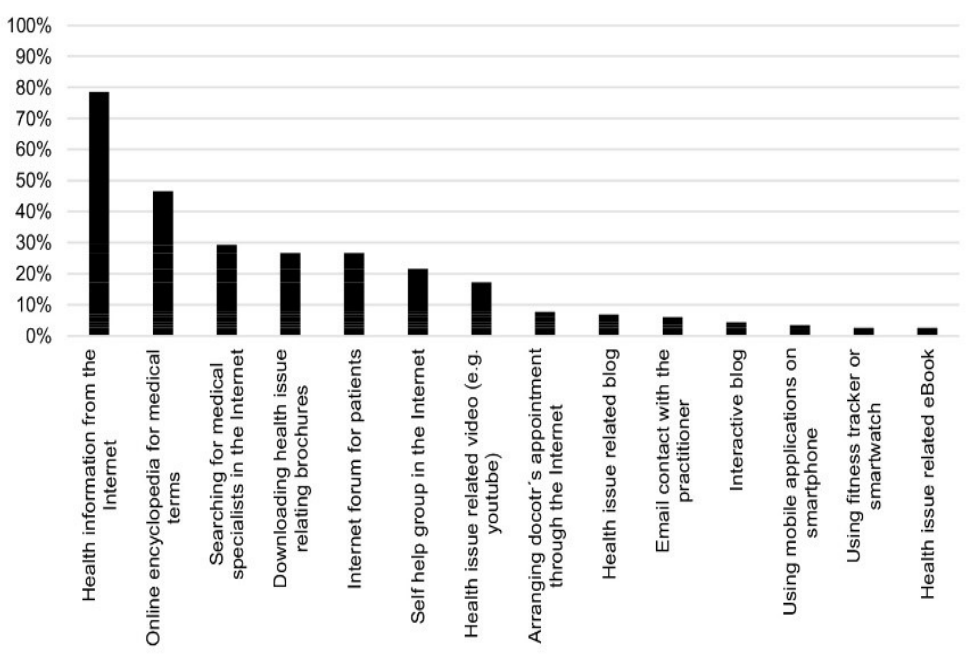

The next item examined if participants felt sure in allocating Internet content into reliable and unreliable information. The mean value was 4.28 and thus, it was the lowest of all items (see Fig. 2). There was no statistically significant difference for this item in respect to gender, level of education and frequent usage of eHealth offers. In this case there was a statistically significant association regarding age $(p=0.047)$. Participants under 51 years old yielded 5.25, while those between 51 and 65 years old reached 3.68 and over 65 years old achieved 4.25 .

The next item evaluated how health-related Internet offers that were already used raised the medical knowledge of our participants. The mean value was 6.33 and ranked among the highest values (see Fig. 2). Concerning gender and level of education there was no statistically significant connection. Yet we found that attendees younger than 51 years scored 7.42 , between 51 and 65 years 6.0 and those older than 65 years yielded 5.92. This result showed, that younger participants could use the Internet better for gaining medical Information for their decision-making process $(p=0.046)$. Participants who regularly used eHealth offers (7.85) also showed statistically significant ( $p=0.036)$ better values than participants who used them irregularly (6.24) or participants who have not used them yet (5.30).

The last two items aimed to assess the usage of innovative mobile health applications. We examined if participants know how they could find suitable Apps for their health care. The mean value was 4.85 and $17.8 \%$ stated that they absolutely don't know how to find suitable Apps. Therefore, attendees younger than 51 years reached the mean value 6.40 in contrast to those older than 65 years who yielded $4.81(p=0.047)$. There was no difference for this item in respect to gender, level of education and frequency of usage of eHealth offers (Fig. 3).

The second item evaluated whether participants know how to use these health Apps through a smartphone or a tablet. The mean value was 4.86 and $18.8 \%$ stated that they absolutely do not know how to use smartphone/tablet Apps. There was no connection regarding gender. Although there was a trend that younger participants were more skilled in using health care Apps there was no statistically significant result $(p=0.505)$. Attendees of lower education level reached higher mean values (5.33) than those of higher education level (4.32) without any statistically significant result $(p=0.155)$. Also, participants who were frequent users of eHealth offers, hence more skilled, scored higher mean values than those who used eHealth offers rarely $(p=0.146)$. There was no association for this item in terms of gender.

The inner consistency of our eHealth literacy items showed a satisfactory reliability tested with Cronbach alpha $=0.851$.

\section{Data on Single Item Literacy Screener (SILS)}

The SILS identifies adults who need help with printed health material by asking: "How often do you need to have someone help you when you read instructions, pamphlets, or other written material from your doctor or pharmacy?". Possible answers were 1-never, 2-rarely, 3sometimes, 4-often and 5-always (Morris et al. 2006). We decided to identify scores greater than 2 as a positive result. Thus, the SILS was positive in $35.2 \%$ of the participants and categorized as "limited reading ability". Of those, $25 \%$ sometimes, $7 \%$ often and $2.1 \%$ always needed help. The arithmetic mean value of all participants was 
Fig. 3 Assessment of eHealth literacy items

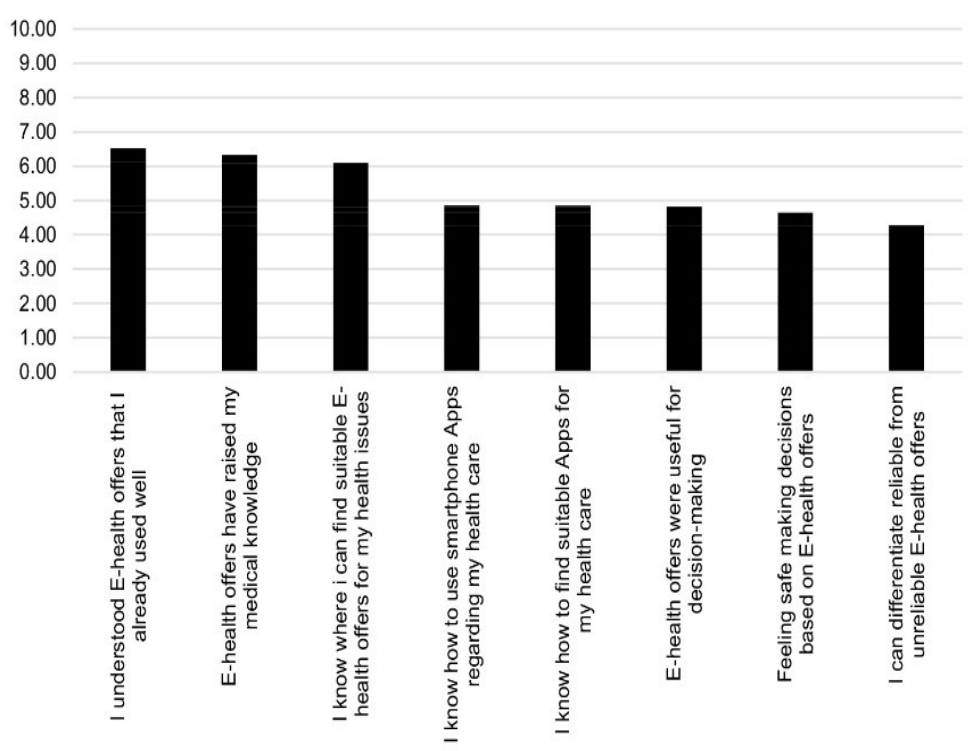

2.2. There was no statistically significant association for the SILS regarding gender, age and level of education. It is interesting that participants under 51 years old presented limited reading-ability in $23.8 \%$, while those $51-65$ years old $32.6 \%$ and those over 65 years old $36.6 \%(p=0.596)$. There was a strong connection between the SILS and the comprehension of eHealth offers that were already used by participants $(p=0.001)$. Participants with adequate reading ability scored a mean value of 7.08 and those with limited reading ability 5.68 .

\section{Data on frequency of using health information resources}

The last part of our questionnaire asked the participants how often they used information sources (i.e. medical staff, relatives, friends, Books, Internet) for their health issues in the last month. The majority (56.4\%) asked 1-4 times a month, followed by $17.3 \%$ who used information sources in 5-9 times a month. There was no association between feeling secure using eHealth offers and the frequency of doing so.

\section{Discussion}

To our knowledge, this study is the first one which used an internally consistent eHealth Literacy Scale developed from formerly published scales and combined this instrument to an examination of the general Internet usage behavior and the usage of eHealth services among cancer patients and relatives. Evaluating the frequency of general Internet usage, we found that younger patients were using the Internet more often than elderly $(p=0.001)$ as it was already reported in other studies (Laurent et al. 2012; Ludgate et al. 2011). Concerning gender, we could not find any difference whereas diverse results can be found in several other studies. Some concluded that the characteristic profile of a frequent Internet user was young, female and well-educated (Dewalt et al. 2004; Eheman et al. 2009; Laurent et al. 2012; Protiere et al. 2012). In contrast, a German study stated that more male, young and well educated people used the Internet for health information seeking (Gerd 2003). Even if the frequency of using eHealth services was not statistically significantly associated with age $(p=0.099)$, there was a trend in our study that younger participants also used them more often comparable with the general Internet usage.

We did not find a statistically significant association between the level of education and the usage of eHealth offers for gaining medical knowledge about the disease. This is also reported in the literature where a serious and life threatening diagnosis like cancer is described as a powerful incentive for both, high and poor educated patients, to seek information and gain knowledge (Lee et al. 2012). This motivation seems to minimize the gap in between high and poor educated patients.

Additionally, we could not find statistically significant associations between education level and the eHealth literacy items. Yet, consistent with the literature, participants with low education showed a poorer comprehension of eHealth services than those with middle and high education $(p=0.002)$.

\section{黑 Springer}


In contrast to the poor comprehension, participants with lower education less often reported feeling insecure while using health information from the Internet. Moreover, poor education goes along with a higher rating of one's own capability to find suitable health Apps. One explanation for this might be that higher education goes along with a more skeptical attitude towards information found on the Internet and a more realistic appraisal of one's own abilities. In fact, higher educated participants were more skeptical whether they would be able to distinguish reliable information from less reliable one.

Accordingly, higher education does not seem to suffice to discern reliable and useful information from less qualified information. As a consequence, besides increasing health literacy, it will be important to improve skills to navigate and analyze health information presented in the Internet or using health applications.

Participants who used eHealth offers regularly more often reported that this expanded their medical knowledge. While, experience seems to be one prerequisite for feeling confident with eHealth offers. Participants using the Internet more often did not rate themselves more skilled in finding eHealth offers for their requirements. Participants who used eHealth services regularly only had a trend to a better assessment of reliability.

The triangular relationship between education level, health outcome and health literacy is well reported in the literature. Low education level and low health literacy are associated with poor health outcomes and vice versa (Howard et al. 2006; Nutbeam 2008; Paasche-Orlow et al. 2005; van der Heide et al. 2013). The ability to decide whether a health information is reliable or not is an important aspect of health literacy (Sevices 2000).

As the Internet most probably soon will become the most often used source of information and Apps and their interactivity will offer big chances to improve health care, eHealth literacy must become an important focus for education. Simply relying on the younger generation being more familiar with the web will not solve the problem.

Adequate reading ability is a prerequisite for searching, finding, assessing and processing health information. Therefore, it is part of health literacy and often used to evaluate the latter. There are several possibilities to measure adequate reading ability, e.g., WRAT (Wide Range Achievement Test), REALM (Rapid Estimate of Adult Literacy in Medicine), TOFLHA (Test of Functional Health Literacy in Adults) and SILS (Single Item Literacy Screener). Except for WRAT, they test reading ability on health related materials (Dewalt et al. 2004). We integrated the SILS into our questionnaire because it was just one question and therefore a very comfortable and fast possibility to evaluate the reading ability on health related information. $35.2 \%$ of our participants had inadequate reading ability. That means that the participants needed sometimes, often or always help with medical information. In the literature there were differing data on reading ability. This may be due to the differing study populations regarding gender, age, ethnicity, level of education and others. One research article found limited reading ability measured by the SILS of 23\% (Morris et al. 2006). Another review that used the TOFLHA revealed that low health literacy was $26 \%$ and marginal health literacy was 20\% (Paasche-Orlow et al. 2005). As proposed in the article of Morris et al., we can combine low and marginal health literacy into one group, which can be referred to as limited reading ability (Morris et al. 2006). That resulted in a limited reading ability of $46 \%$.

We assessed the association between reading ability and our comprehension item on eHealth related services and found a highly significant correlation $(p=0.001)$. Yet, eHealth literacy comprises many more features which must be addressed in trainings for lay people in order to safely integrate eHealth services in the health care system. Furthermore, eHealth literacy is not a static construction, it is evolving and adapting influenced by the six core skills (traditional literacy, health literacy, information literacy, scientific literacy, media literacy, and computer literacy) proposed in "The lily model" (Norman and Skinner 2006b). Such a comprehensive training might help to reduce the gap between available electronic resources and the patients' capability to use them.

In fact, we urgently need more detailed research on when, how and to whom a skills training for eHealth literacy should be designed. Most urgently needed are skills trainings for rating the trustworthiness as well as the applicability of the information on one's own situation.

The main limitation of our survey is that the sample is not representative. Participants who answered the questionnaires were attending lectures on complementary and alternative medicine (CAM). In the literature it is well known that the clientele is usually female, highly educated and highly motivated in gaining medical knowledge concerning their disease (Huebner et al. 2014; Paul et al. 2013) which is consistent with our demographic data indicating that $64 \%$ were female. A further limitation is that a part of the participants were preselected by the sponsoring public health insurance company "Techniker Krankenkasse" that actively invited their insurees from the regional disease management programs for breast cancer patients (35\%). This clientele is also known to be highly educated. This also explains the major proportion of higher educated participants in our sample (see Table 1). 


\section{Conclusion}

The results of our questionnaire showed that the Internet was an important factor of providing health material- $50.4 \%$ were using the Internet daily. The younger the participants were or the better the Internet connection was, the more often the Internet was used. Most frequently the participants used eHealth "health-related information from the Internet". We proved that both, higher educated and younger participants understood eHealth services better than poor educated and elderly. Younger attendees or those who were using eHealth services regularly were able to use health-related Internet services better for their decision-making process compared to older ones and ones who were using them rarer. We also identified that younger participants were both more confident in allocating healthrelated Internet information into reliable or unreliable facts and more capable of gaining medical knowledge through eHealth services. The latter was also associated with the frequency of usage of eHealth services. Younger participants even knew better how to find suitable health Apps for their health care. Approximately one-third of our attendees had limited reading ability. Participants with adequate reading abilities had a better understanding regarding to eHealth services.

The two items with the lowest mean value were "I feel safe making decisions based on eHealth services" and "I can differentiate reliable from unreliable eHealth services". These answers point to the low confidence of the participants in their eHealth literacy and ability to profit from Internet usage regarding health care.

For physicians besides providing understandable health Information promoting eHealth literacy in patients may be an upcoming task. Raising awareness on the benefits from eHealth services may be in focus of a continuous health care education. Further research is needed to comprehend the information needs and the usage behavior of eHealth services of our patients to improve their eHealth literacy skills and hence their medical condition and satisfaction with health care.

\section{Compliance with ethical standards}

Conflict of interest The authors declare no conflict of interest.

Research involving human participants and/or animals The study has a positive vote of the ethics committee at the University Hospital of the Friedrich Schiller University at Jena (Number: 5153-05/17).

Informed consent Informed consent was given by the participants by filling in the questionnaire.

Funding There was no funding for this study.

\section{References}

Arora NK, Hesse BW, Rimer BK, Viswanath K, Clayman ML, Croyle RT (2008) Frustrated and confused: the American public rates its cancer-related information-seeking experiences. J Gen Intern Med 23:223-228. doi:10.1007/s11606-007-0406-y

Barnes MD, Penrod C, Neiger BL, Merrill RM, Thackeray R, Eggett DL, Thomas E (2003) Measuring the relevance of evaluation criteria among health information seekers on the Internet. J Health Psychol 8:71-82. doi:10.1177/1359105303008001436

Collins SA, Currie LM, Bakken S, Vawdrey DK, Stone PW (2012) Health literacy screening instruments for eHealth applications: a systematic review. J Biomed Inform 45:598-607. doi:10.1016/j. jbi.2012.04.001

Dewalt DA, Berkman ND, Sheridan S, Lohr KN, Pignone MP (2004) Literacy and health outcomes: a systematic review of the literature. J Gen Intern Med 19:1228-1239. doi:10.1111/j.1525-1497.2004.40153.x

Ebel MD, Stellamanns J, Keinki C, Rudolph I, Huebner J (2015) Cancer patients and the Internet: a survey among German cancer patients. J Cancer Educ. doi:10.1007/s13187-015-0945-6

Eheman CR et al (2009) Information-seeking styles among cancer patients before and after treatment by demographics and use of information sources. J Health Commun 14:487-502. doi: 10.1080/10810730903032945

Feufel MA, Stahl SF (2012) What do web-use skill differences imply for online health information searches? J Med Internet Res 14:e87. doi:10.2196/jmir.2051

Friedman DB, Hoffman-Goetz L (2008) Literacy and health literacy as defined in cancer education research: a systematic review. Health Educ J 67:285-304. doi:10.1177/0017896908097071

Gerd M (2003) Auf der Suche nach gesundheitlicher Information und Beratung: Befunde zum Wandel der Patientenrolle. Gesundheitsmonitor 2003, Die ambulante Versorgung aus Sicht von Bevölkerung und Ärzteschaft. Verlag Bertelsmann Stiftung, Gütersloh

Gustafson DH et al (2008) Internet-based interactive support for cancer patients: are integrated systems better? J Commun 58:238257. doi:10.1111/j.1460-2466.2008.00383.x

Halbach SM, Enders A, Kowalski C, Pfortner TK, Pfaff H, Wesselmann S, Ernstmann N (2016) Health literacy and fear of cancer progression in elderly women newly diagnosed with breast cancer-a longitudinal analysis. Patient Educ Couns 99:855862. doi:10.1016/j.pec.2015.12.012

Howard DH, Sentell T, Gazmararian JA (2006) Impact of health literacy on socioeconomic and racial differences in health in an elderly population. J Gen Intern Med 21:857-861. doi:10.1111/j.1525-1497.2006.00530.x

Huebner J et al (2014) User rate of complementary and alternative medicine (CAM) of patients visiting a counseling facility for $\mathrm{CAM}$ of a German comprehensive cancer center. Anticancer Res 34:943-948

Institute of Medicine Committee on Health L (2004). In: NielsenBohlman L, Panzer AM, Kindig DA (eds) Health literacy: a prescription to end confusion. National Academies Press (US) Copyright 2004 by the National Academy of Sciences. All rights reserved, Washington (DC). doi:10.17226/10883

Jones R (2013) Development of a questionnaire and cross-sectional survey of patient eHealth readiness and eHealth inequalities. Medicine 20(2):e9. doi:10.2196/med20.2559

Keinki $C$ et al (2016) Information needs of cancer patients and perception of impact of the disease, of self-efficacy, and locus of control. J Cancer Educ 31:610-616. doi:10.1007/ s13187-015-0860-x 
Laurent MR, Cremers S, Verhoef G, Dierickx D (2012) Internet use for health information among haematology outpatients: a crosssectional survey. Inform Health Soc Care 37:62-73. doi:10.3109/ 17538157.2011.606481

Lee CJ, Ramirez AS, Lewis N, Gray SW, Hornik RC (2012) Looking beyond the Internet: examining socioeconomic inequalities in cancer information seeking among cancer patients. Health Commun 27:806-817. doi:10.1080/10410236.2011.647621

Ludgate MW et al (2011) Internet use and anxiety in people with melanoma and nonmelanoma skin cancer. Dermatol Surg 37:1252 1259. doi:10.1111/j.1524-4725.2011.02124.x

Morris NS, MacLean CD, Chew LD, Littenberg B (2006) The Single Item Literacy Screener: evaluation of a brief instrument to identify limited reading ability. BMC Fam Pract 7:21. doi:10.1186/1471-2296-7-21

Norman CD, Skinner HA (2006a) eHEALS: the eHealth literacy scale. J Med Internet Res 8:e27. doi:10.2196/jmir.8.4.e27

Norman CD, Skinner HA (2006b) eHealth literacy: essential skills for consumer health in a networked world. J Med Internet Res 8:e9. doi:10.2196/jmir.8.2.e9

Nutbeam D (2008) The evolving concept of health literacy. Soc Sci Med (1982) 67:2072-2078. doi:10.1016/j. socscimed.2008.09.050

Paasche-Orlow MK, Parker RM, Gazmararian JA, NielsenBohlman LT, Rudd RR (2005) The prevalence of limited health literacy. J Gen Intern Med 20:175-184 doi:10.1111/j.1525-1497.2005.40245.x

Paul M et al (2013) Patients with advanced cancer and their usage of complementary and alternative medicine. J Cancer Res Clin Oncol 139:1515-1522. doi:10.1007/s00432-013-1460-y

Protiere C, Moumjid N, Bouhnik AD, Le Corroller Soriano AG, Moatti JP (2012) Heterogeneity of cancer patient informationseeking behaviors. Med Decis Mak 32:362-375. doi:10.1177/0 $272989 \times 11415114$
Ratzan SC, Parker RM (2000) Introduction. In: Selden CR, Zorn M, Ratzan SC (eds) National library of medicine current bibliographies in medicine: health literacy. National Institutes of Health, U.S. Department of Health and Human Services, Bethesda

Richards B, Colman AW, Hollingsworth RA (1998) The current and future role of the Internet in patient education. Int J Med Informatics 50:279-285

Sevices USDoHAH (2000) Healthy People 2010

Simonds SK (1974) Health education as social policy. Health Educ Monogr 2:1-10. doi:10.1177/10901981740020S102

Sorensen K, Van den Broucke S, Fullam J, Doyle G, Pelikan J, Slonska Z, Brand H (2012) Health literacy and public health: a systematic review and integration of definitions and models. BMC Public Health 12:80. doi:10.1186/1471-2458-12-80

van der Heide I, Wang J, Droomers M, Spreeuwenberg P, Rademakers J, Uiters E (2013) The relationship between health, education, and health literacy: results from the Dutch Adult Literacy and Life Skills Survey. J Health Commun 18(Suppl 1):172-184. doi: $10.1080 / 10810730.2013 .825668$

Ventura F, Ohlen J, Koinberg I (2013) An integrative review of supportive e-health programs in cancer care. Eur J Oncol Nurs 17:498-507. doi:10.1016/j.ejon.2012.10.007

Warren E, Footman K, Tinelli M, McKee M, Knai C (2014) Do cancer-specific websites meet patient's information needs? Patient Educ Couns 95:126-136. doi:10.1016/j.pec.2013.12.013

Wasserman M, Baxter NN, Rosen B, Burnstein M, Halverson AL (2014) Systematic review of internet patient information on colorectal cancer surgery. Dis Colon Rectum 57:64-69. doi:10.1097/ dcr.0000000000000011

Zok K (2/2014) Unterschiede bei der Gesundheitskompetenz Ergebnisse einer bundesweiten Repräsentativ-Umfrage unter gesetzlich Versicherten. AOK 


\section{Diskussion}

Der vorliegenden Arbeit liegt eine eHealth Literacy Skala von hoher interner Konsistenz (Cronbach alpha $=0,851)$ zugrunde. Die Bestandteile der Skala wurden aus publizierten Veröffentlichungen extrahiert (Jones 2013; Norman and Skinner 2006a), kombiniert und erweitert, um das Internetnutzungsverhalten sowie den Gebrauch von eHealth Anwendungen von Krebspatienten und deren Angehörigen zu messen und zu analysieren.

Die Ergebnisse dieser Arbeit zeigten, dass jüngere Teilnehmer das Internet generell statistisch signifikant häufiger nutzten als Ältere, wie bereits in anderen Studien erhoben (Laurent et al. 2012; Ludgate et al. 2011). Insbesondere bei der Inanspruchnahme von eHealth Angeboten zeichnete sich $\mathrm{ab}$, dass diese häufiger von jüngeren Teilnehmern genutzt wurden, wobei hier kein statistisch signifikantes Ergebnis ermittelt werden konnte.

Es ließen sich keine statistisch signifikanten geschlechtsspezifischen Unterschiede in der Internetnutzung feststellen. Diesbezüglich gab es in der Literatur uneinheitliche Angaben. Das charakteristische Internetnutzerprofil wurde in mehreren Publikationen als jung, weiblich und gebildet ermittelt (Dewalt et al. 2004; Eheman et al. 2009; Laurent et al. 2012; Protiere et al. 2012). Eine deutsche Studie hingegen kam zu dem Ergebnis, dass gerade das männliche Geschlecht mit einer häufigeren Nutzung des Internets assoziiert war (Gerd 2003). Einigkeit bestand darin, dass jüngeres Alter sowie höherer Bildungsgrad mit einer häufigeren Nutzung des Internets im Zusammenhang standen.

Betrachtet man die Häufigkeit der Nutzung von eHealth Angeboten in den unterschiedlichen Bildungsniveaus, so zeigten die Ergebnisse keine statistisch signifikanten Unterschiede. Eine Erklärung hierfür könnte sein, dass eine schwere und lebensbedrohliche Erkrankung, wie zum Beispiel eine Tumorerkrankung, sowohl Menschen mit hohem als auch niedrigem Bildungsstand dazu motiviert sich über die Erkrankung zu informieren und eHealth Angebote zu nutzen. Nach Lee et al. gleicht dieser Motivationsanreiz Bildungsunterschiede aus (2012).

Die Analyse der eHealth Kompetenzitems ergab, dass Teilnehmer mit niedrigerem Bildungsstand eHealth Angeboten schlechter erfassen konnten als Teilnehmer mit höherem Bildungsniveau. Weiterhin konnten keine statistisch signifikanten Assoziationen bezüglich der eHealth Kompetenzitems und dem Bildungsstand festgestellt werden. Interessanterweise gaben Teilnehmer, die der Gruppe mit geringem Bildungsstand angehörten, an, dass sie sich bei Therapieentscheidungen, die auf Gesundheitsinformationen aus dem Internet basierten, sicherer fühlten als Teilnehmer aus der mittleren oder hohen Bildungsschicht. Zudem zeigten 
die Ergebnisse, dass Teilnehmer mit geringerer Bildung ihre Fähigkeit, geeignete Gesundheits-Apps zu finden, besser einschätzten als Teilnehmer höherer Bildungsschichten. Eine mögliche Erklärung hierfür könnte sein, dass höher gebildete Teilnehmer Inhalte aus dem Internet weitaus skeptischer und bedenklicher beurteilen und daher auch ihre eigenen Fähigkeiten, geeignete Gesundheits-Apps zu finden, in Frage stellen. Einhergehend mit dieser möglichen Erklärung zeigten die Ergebnisse, dass sich Teilnehmer aus der höheren Bildungsgruppe bei der Zuordnung von zuverlässigen und unzuverlässigen eHealth Angeboten deutlich schlechter einschätzten, als Teilnehmer der mittleren und niedrigen Bildungsschicht. Folglich scheint ein höheres Bildungsniveau nicht vor Unsicherheiten und Zweifeln, hinsichtlich Gesundheitsinformationen aus dem Internet, zu schützen. Des Weiteren stellt sich die Frage, was diese Unsicherheit aufrechterhält und wie man dieser begegnen kann. Dabei spielt die Förderung der eHealth Literacy eine entscheidende Rolle.

Teilnehmer, die bereits häufiger eHealth Angebote genutzt haben und somit erfahrener im Umgang mit Gesundheitsinformationen aus dem Internet waren, berichteten häufiger, dass sie ihr medizinisches Wissen dadurch erweitern konnten. Obwohl die Erfahrung im Umgang mit Gesundheitsinformationen aus dem Internet eine Rolle $\mathrm{zu}$ spielen schien, schätzten sich versierte Teilnehmer beim Finden von hilfreichen eHealth Angeboten nicht besser ein als Teilnehmer, die das Internet seltener nutzten. Allerdings zeigten die Ergebnisse die Tendenz, dass Teilnehmer, die das Internet häufiger nutzten, sicherer in der Zuordnung von zuverlässigen und unzuverlässigen Internetquellen waren. Eine Erklärung hierfür könnte sein, dass die Teilnehmer weniger mit dem Inhalt der Internetseiten Probleme hatten als vielmehr mit der Navigation durch das World Wide Web.

Der Gesundheitsstatus, der Bildungsstand und der Grad der Health Literacy stehen in enger wechselseitiger Verbindung. So stehen ein geringer Bildungsgrad und unzureichende Health Literacy im Zusammenhang mit einem schlechteren Gesundheitsstatus und umgekehrt. Diese trianguläre Beziehung wurde bereits häufig in der Literatur beschrieben (Howard et al. 2006; Nutbeam 2008; Paasche-Orlow et al. 2005; van der Heide et al. 2013).

$50,4 \%$ der Teilnehmer gaben an das Internet täglich zu nutzen. Demgegenüber nutzten 30,2 $\%$ das Internet mehrmals pro Woche. Wobei 77,7 \% der Teilnehmer die Angabe machten, ihre Internetverbindung sei schnell genug für ihre Bedürfnisse. Dies verdeutlicht die einfache Zugänglichkeit und die weite Verbreitung des Internets. Die Entwicklung neuer elektronischer Geräte, wie zum Beispiel: Tablet-Computer, Smartphone, Smartwatch und Fitnessarmband mit geeigneter App, die den Zugriff auf eHealth Angebote erleichtern, schreiten mit rasanter Geschwindigkeit voran und bieten durch ihren interaktiven Charakter die Möglichkeit die 
Gesundheit der Patienten positiv zu beeinflussen. Wie oben dargestellt, ist das Alter sowohl mit der Nutzung des Internets als auch der Nutzung von eHealth Angeboten assoziiert. Es ist jedoch nicht zielführend, sich auf die technikversierte jüngere Generation zu beschränken. Hierzu gibt es bereits computerbasierte Programme, wie CHESS (Comprehensive Health Enhancement Support System). Dieses besteht aus drei Säulen: Informationsservice, Kommunikationsservice und Entscheidungshilfe. Das Programm versorgt die Patienten mit Gesundheitsinformationen, wie zum Beispiel: aufbereitete Gesundheitsinformationen, Verweise an qualitativ hochwertige Webseiten und Adressen von Fachspezialisten. Zudem gibt es ein Forum, das Antworten auf häufig gestellte Fragen beinhaltet, sowie Austauschforen für Patienten. Gustafson et al. zeigten, dass Patienten durchaus von solchen Gesundheitsprogrammen profitieren, da sie diese während des Krankheitsverlaufes unterstützen (2008). Mit einer Onlineplattform, wie dieser, versucht man Patienten durch die Informationsflut des Internets $\mathrm{zu}$ steuern und ihnen bei der Suche nach Gesundheitsinformationen behilflich zu sein. Die Vorteile von eHealth Angeboten, wie CHESS, sollten daher von Patienten aller Altersgruppen genutzt werden können.

Das Leseverständnis ist ein wichtiger Bestandteil von eHealth Literacy und ermöglicht es erst Gesundheitsinformationen $\mathrm{zu}$ suchen, $\mathrm{zu}$ finden, $\mathrm{zu}$ verstehen und $\mathrm{zu}$ verarbeiten. Deshalb wurden verschiedene Testinstrumente entwickelt, um das Leseverständnis im Hinblick auf medizinische Sachverhalte zu messen. Häufig werden WRAT (Wide Range Achievement Test), REALM, TOFLHA und SILS verwendet (Dewalt et al. 2004). In dieser Studie wurde das Testinstrument SILS aus folgenden Gründen angewandt: WRAT misst das Leseverständnis unabhängig vom medizinischen Kontext. Die benötigte Zeit für die Erhebung der Daten bei REALM beträgt im Durchschnitt drei Minuten und bei TOFLHA zwölf Minuten. SILS hingegen besteht aus einer einzelnen Frage. Somit ist er leicht verständlich und schnell zu erheben. Die Testfrage des SILS lautet: „Wie häufig benötigen Sie die Hilfe anderer Personen beim Lesen von medizinischen Anweisungen, Broschüren oder anderem schriftlichem Material, das Sie von Ihrem Arzt/Apotheker bekommen haben?“ (Morris et al. 2006). Die Ergebnisse zeigten, dass 35,2 \% der Teilnehmer immer, oft oder manchmal Hilfe benötigten und damit ein unzureichendes Leseverständnis aufwiesen. In der Literatur wurden unterschiedliche Zahlen hinsichtlich des Leseverständnisses erhoben. Dies lag möglicherweise an den verschiedenen Faktoren der Studienpopulationen, wie zum Beispiel: Alter, Geschlecht, Ethnizität, Bildungsschicht, Einkommen und Weitere. Zum Anderen ist die Wahl des Cut Offs zu berücksichtigen. Die Antwortmöglichkeiten waren: 1 = nie, 2 = selten, $3=$ manchmal, $4=$ oft und $5=$ immer. In der vorliegenden Studie wurden Werte größer als 2 
positiv gewertet und zur Gruppe mit unzureichendem Leseverständnis gezählt. Morris et al. wählten in ihrer Studie denselben Cut Off und zeigten, dass $23 \%$ der Teilnehmer immer, oft oder manchmal Hilfe beim Lesen von medizinischen Informationen benötigten (2006). In einem Review von Paasche-Orlow et al. wurde TOFLHA herangezogen, um das medizinische Leseverständnis zu untersuchen. Dabei wiesen $26 \%$ ein niedriges und $20 \%$ ein marginales Leseverständnis auf (2005). Fasst man niedriges und marginales Leseverständnis zusammen, wie es Morris et al. vorschlugen, so ergibt sich ein unzureichendes Leseverständnis bei $46 \%$ der Teilnehmer (2006). Die Schwachstelle beim Vergleich der Ergebnisse von SILS und TOFLHA liegt darin, dass sie nicht exakt das Gleiche messen. Da SILS nicht direkt das Leseverständnis misst, sondern den Bedarf an Hilfestellung bei medizinischen Informationen. Die Ergebnisse dieser Studie zeigten auch, dass Teilnehmer, die über ein adäquates Leseverständnis verfügten, höhere Werte beim Verständnis von eHealth Angeboten, die bereits genutzt wurden, erzielten.

Hervorzuheben ist, das eHealth Literacy weitaus mehr als nur das Leseverständnis beinhaltet. Dies wurde durch „The lily model“" von Norman und Skinner herausgearbeitet. Danach bilden sechs Kernkompetenzen die Grundlage von eHealth Literacy. Die Kernkompetenzen, Medienverständnis und Computertechnologieverständnis, verdeutlichen, dass eHealth Literacy kein starres Konstrukt ist, sondern sich vielmehr an die Gesellschaft und an den technologischen Fortschritt adaptiert (Norman and Skinner 2006b). Die Förderung der Kernkompetenzen und damit von eHealth Literacy könnte dabei helfen die Schlucht zwischen den verfügbaren eHealth Angeboten und den Fähigkeiten der Teilnehmer diese zu nutzen zu überwinden. Die Fähigkeit, zuverlässige von unzuverlässigen Gesundheitsinformationen aus dem Internet zu unterscheiden, erzielte den niedrigsten Durchschnittswert von 4,28 in den eHealth Literacy Items. Dies bildet einen Ansatzpunkt für die Unterstützung von Patienten und deren Angehörigen.

Die Hauptlimitation dieser Arbeit stellte die Studienpopulation dar, die nicht repräsentativ war. Die Teilnehmer beantworteten die Fragebögen, während der Teilnahme an Vorträgen zur Komplementär- und Alternativmedizin. Studien zeigten, dass die charakteristischen Eigenschaften der Teilnehmer weiblich, hoher Bildungsgrad und hochmotiviert, sich medizinisches Wissen anzueignen, sind (Huebner et al. 2014; Paul et al. 2013). Diese Charakteristika spiegelten sich in den demographischen Daten dieser Arbeit wieder. Außerdem wurde ein Teil der Studienpopulation, der sich in Disease-ManagementProgrammen befand, von der Techniker Krankenkasse eingeladen. Es ist bekannt, dass Teilnehmer von Disease-Management-Programmen über einen durchschnittlich höheren 
Bildungsgrad verfügen. Dies erklärt auch den Anteil an Teilnehmern mit hohem Bildungsstand von 39,4 \% in der vorliegenden Studie. 


\section{Schlussfolgerung}

Die Ergebnisse des Fragebogens zeigten, dass das Internet von 50,4 \% der Teilnehmer täglich genutzt wurde und als Quelle für Gesundheitsinformationen unter den eHealth Angeboten am häufigsten vertreten war. Sowohl das Alter als auch der Bildungsgrad der Teilnehmer spielten in vielerlei Beziehungen eine beachtliche Rolle. Je jünger die Teilnehmer, desto häufiger nutzten sie das Internet sowie eHealth Angebote und waren routinierter im Aufsuchen von Gesundheits-Apps. Des Weiteren stellte sich heraus, dass Teilnehmer mit höherem Bildungsgrad und jüngerem Lebensalter ein besseres Verständnis für eHealth Angebote aufwiesen. Weiterhin waren jüngere Teilnehmer erfolgreicher darin, Gesundheitsinformationen aus dem Internet für ihre Therapieentscheidungen zu nutzen, zuverlässige Gesundheitsinformationen von unzuverlässigen Inhalten zu unterscheiden und eHealth Angebote für ihren Wissenszuwachs heranzuziehen. Neben dem Alter der Teilnehmer war auch die Häufigkeit der Internetnutzung sowie die Frequenz der Nutzung von eHealth Angeboten mit einigen eHealth Literacy Items assoziiert. Probanden, die das Internet regelmäßig verwendeten, konnten einen größeren Vorteil aus netzbasierten Gesundheitsinformationen für ihre Therapieentscheidungen ziehen, als Teilnehmer, die das Internet unregelmäßig oder selten in Anspruch nahmen. Teilnehmer, die eHealth Angebote bereits häufiger gebrauchten, waren in der Lage ihr medizinisches Wissen effektiver zu erweitern. 35,2 \% der Teilnehmer besaßen ein unzureichendes Leseverständnis. Es stellte sich heraus, dass Teilnehmer mit adäquatem Leseverständnis auch ein besseres Verständnis bei der Nutzung von eHealth Angeboten aufwiesen. Die eHealth Literacy Items mit den niedrigsten Durchschnittswerten waren „Ich fühle mich sicher, wenn ich Entscheidungen zu meiner Gesundheit auf der Basis von Gesundheitsinformationen aus dem Internet treffen muss“ und „Bei der Nutzung von Gesundheitsinformationen aus dem Internet weiß ich sicher, ob diese Informationen aus zuverlässigen oder unzuverlässigen Quellen stammen“. Dies verdeutlichte die geringe Zuversicht der Teilnehmer in ihre eHealth Literacy Fähigkeiten und damit verbunden den verminderten Benefit von eHealth Angeboten für gesundheitliche Belange.

Neben der Bereitstellung von Gesundheitsinformationen könnte es schon bald Aufgabe der Ärzte sein, Maßnahmen zur Förderung der eHealth Literacy von Patienten zu ergreifen. Weitere Untersuchungen und Studien sind notwendig, um das Informationsbedürfnis und das Nutzungsverhalten von eHealth Angeboten der Patienten zu erfassen, ihre Defizite zu identifizieren und dadurch ihre eHealth Literacy zu verbessern. 


\section{Literatur- und Quellenverzeichnis}

Arora NK, Hesse BW, Rimer BK, Viswanath K, Clayman ML, Croyle RT (2008) Frustrated and confused: the American public rates its cancer-related information-seeking experiences Journal of general internal medicine 23:223-228 doi:10.1007/s11606-0070406-y

Barnes MD, Penrod C, Neiger BL, Merrill RM, Thackeray R, Eggett DL, Thomas E (2003) Measuring the Relevance of Evaluation Criteria among Health Information Seekers on the Internet Journal of health psychology 8:71-82 doi:10.1177/1359105303008001436

Collins SA, Currie LM, Bakken S, Vawdrey DK, Stone PW (2012) Health literacy screening instruments for eHealth applications: a systematic review Journal of biomedical informatics 45:598-607 doi:10.1016/j.jbi.2012.04.001

Dewalt DA, Berkman ND, Sheridan S, Lohr KN, Pignone MP (2004) Literacy and health outcomes: a systematic review of the literature Journal of general internal medicine 19:1228-1239 doi:10.1111/j.1525-1497.2004.40153.x

Ebel MD, Stellamanns J, Keinki C, Rudolph I, Huebner J (2015) Cancer Patients and the Internet: a Survey Among German Cancer Patients Journal of cancer education : the official journal of the American Association for Cancer Education doi:10.1007/s13187-015-0945-6

Eheman CR et al. (2009) Information-seeking styles among cancer patients before and after treatment by demographics and use of information sources Journal of health communication 14:487-502 doi:10.1080/10810730903032945

Feufel MA, Stahl SF (2012) What do web-use skill differences imply for online health information searches? Journal of medical Internet research 14:e87 doi:10.2196/jmir.2051 
Gerd M (2003) Auf der Suche nach gesundheitlicher Information und Beratung: Befunde zum Wandel der Patientenrolle. Gesundheitsmonitor 2003, Die ambulante Versorgung aus Sicht von Bevölkerung und Ärzteschaft. Verlag Bertelsmann Stiftung, Gütersloh

Gustafson DH et al. (2008) Internet-Based Interactive Support for Cancer Patients: Are Integrated Systems Better? The Journal of communication 58:238-257 doi:10.1111/j.1460-2466.2008.00383.x

Halbach SM, Enders A, Kowalski C, Pfortner TK, Pfaff H, Wesselmann S, Ernstmann N (2016) Health literacy and fear of cancer progression in elderly women newly diagnosed with breast cancer--A longitudinal analysis Patient education and counseling 99:855-862 doi:10.1016/j.pec.2015.12.012

Howard DH, Sentell T, Gazmararian JA (2006) Impact of health literacy on socioeconomic and racial differences in health in an elderly population Journal of general internal medicine 21:857-861 doi:10.1111/j.1525-1497.2006.00530.x

Huebner J et al. (2014) User rate of complementary and alternative medicine (CAM) of patients visiting a counseling facility for CAM of a German comprehensive cancer center Anticancer research 34:943-948

Institute of Medicine Committee on Health L (2004). In: Nielsen-Bohlman L, Panzer AM, Kindig DA (eds) Health Literacy: A Prescription to End Confusion. National Academies Press (US)

Copyright 2004 by the National Academy of Sciences. All rights reserved., Washington (DC). doi:10.17226/10883

Jones R (2013) Development of a Questionnaire and Cross-Sectional Survey of Patient eHealth Readiness and eHealth Inequalities Medicine 20 2:e9 doi:10.2196/med20.2559

Laurent MR, Cremers S, Verhoef G, Dierickx D (2012) Internet use for health information among haematology outpatients: a cross-sectional survey Inform Health Soc Care 37:62-73 doi:10.3109/17538157.2011.606481 
Lee CJ, Ramirez AS, Lewis N, Gray SW, Hornik RC (2012) Looking beyond the Internet: examining socioeconomic inequalities in cancer information seeking among cancer patients Health communication 27:806-817 doi:10.1080/10410236.2011.647621

Ludgate MW et al. (2011) Internet use and anxiety in people with melanoma and nonmelanoma skin cancer Dermatologic surgery : official publication for American Society for Dermatologic Surgery [et al] 37:1252-1259 doi:10.1111/j.15244725.2011.02124.x

Morris NS, MacLean CD, Chew LD, Littenberg B (2006) The Single Item Literacy Screener: evaluation of a brief instrument to identify limited reading ability BMC family practice 7:21 doi:10.1186/1471-2296-7-21

Norman CD, Skinner HA (2006a) eHEALS: The eHealth Literacy Scale Journal of medical Internet research 8:e27 doi:10.2196/jmir.8.4.e27

Norman CD, Skinner HA (2006b) eHealth Literacy: Essential Skills for Consumer Health in a Networked World Journal of medical Internet research 8:e9 doi:10.2196/jmir.8.2.e9

Nutbeam D (2008) The evolving concept of health literacy Social science \& medicine (1982) 67:2072-2078 doi:10.1016/j.socscimed.2008.09.050

Paasche-Orlow MK, Parker RM, Gazmararian JA, Nielsen-Bohlman LT, Rudd RR (2005) The prevalence of limited health literacy Journal of general internal medicine 20:175184 doi:10.1111/j.1525-1497.2005.40245.x

Paul M et al. (2013) Patients with advanced cancer and their usage of complementary and alternative medicine Journal of cancer research and clinical oncology 139:1515-1522 doi:10.1007/s00432-013-1460-y

Protiere C, Moumjid N, Bouhnik AD, Le Corroller Soriano AG, Moatti JP (2012) Heterogeneity of cancer patient information-seeking behaviors Medical decision 
making : an international journal of the Society for Medical Decision Making 32:362375 doi:10.1177/0272989x11415114

Sevices USDoHAH (2000) Healthy People 2010

Simonds SK (1974) Health Education as Social Policy Health Education Monographs 2:1-10 doi:doi:10.1177/10901981740020S102

Sorensen K, Van den Broucke S, Fullam J, Doyle G, Pelikan J, Slonska Z, Brand H (2012) Health literacy and public health: a systematic review and integration of definitions and models BMC public health 12:80 doi:10.1186/1471-2458-12-80

van der Heide I, Wang J, Droomers M, Spreeuwenberg P, Rademakers J, Uiters E (2013) The relationship between health, education, and health literacy: results from the Dutch Adult Literacy and Life Skills Survey Journal of health communication 18 Suppl 1:172-184 doi:10.1080/10810730.2013.825668

Wasserman M, Baxter NN, Rosen B, Burnstein M, Halverson AL (2014) Systematic review of internet patient information on colorectal cancer surgery Diseases of the colon and rectum 57:64-69 doi:10.1097/dcr.0000000000000011

Zok K (2/2014) Unterschiede bei der Gesundheitskompetenz Ergebnisse einer bundesweiten Repräsentativ-Umfrage unter gesetzlich Versicherten. AOK, 


\section{Anhang}

\subsection{Fragebogen}

\section{Sehr geehrte Damen und Herren,}

oft müssen Sie schwierige Entscheidungen treffen. Dies fällt Ihnen leichter, wenn Sie gut informiert sind. Wie wichtig ist für Sie das Internet als Informationsquelle? Was können wir tun, um es besser zu machen?

Dieser Fragebogen ist freiwillig und anonym. Er wird von wissenschaftlichen Mitarbeitern/innen der Deutschen Krebsgesellschaft ausgewertet.

1. Zu Beginn des Fragebogens möchten wir Sie bitten, ein paar Angaben zu Ihrer Person zu machen:

$\mathrm{Zu}$ welcher Personengruppe gehören Sie?

Patient/-in, zurzeit in Behandlung $\quad \square \quad$ Patient/-in, nach der Behandlung

Angehörige/r $\quad \square \quad$ Sonstiges

Alter: Tumorart:

Geschlecht: $\square$ männlich $\square$ weiblich Jahr der Erstdiagnose:

1. Welches ist Ihr höchster Schulabschluss?

○ Kein Abschluss

○ Grundschule

- Hauptschule/Volksschule

- Realschule/mittlere Reife

○ Fachhochschulreife/Fachabitur

- Allgemeine Hochschulreife/Abitur 
○ Hochschulabschluss

○ Anderes

2. Wie häufig nutzten Sie in den letzten drei Monaten das Internet - und zwar egal, ob beruflich oder privat - und auch egal, ob mobil von unterwegs oder von einem festen Rechner aus und auch egal zu welchem Zweck?

○ täglich

- mehrmals in der Woche

○ mehrmals im Monat

○ seltener

$\circ$ nie

3. Bitte vervollständigen Sie diesen Satz: Ich habe zu Hause...

○ ...eine Internetverbindung, die schnell genug ist für das, was ich brauche

$\bigcirc \quad$...eine Internetverbindung, die zu langsam ist, für das was ich brauche

○ ...keine Internetverbindung

○ Ich weiß nicht

4. Wo und wie haben Sie das Internet in den letzten drei Monaten genutzt? (Mehrfachantwort möglich)

○ Desktop/Laptop Computer zu Hause

- Smartphone oder anderes mobiles Gerät (z.B. Tablet)

○ Desktop/Laptop Computer in der Arbeit

○ Internetzugang in einem Café, am Flughafen, in einem Geschäft oder einem anderen öffentlichen Ort

○ Ich habe das Internet in den letzten drei Monaten nicht genutzt (Bitte fahren Sie fort mit Frage 15.) 


\section{Elektronische Gesundheitsdienste (z.B. Internetseiten zu Gesundheitsdiensten,} Gesundheitsforen im Internet, Gesundheitsanwendungen auf dem Smartphone)

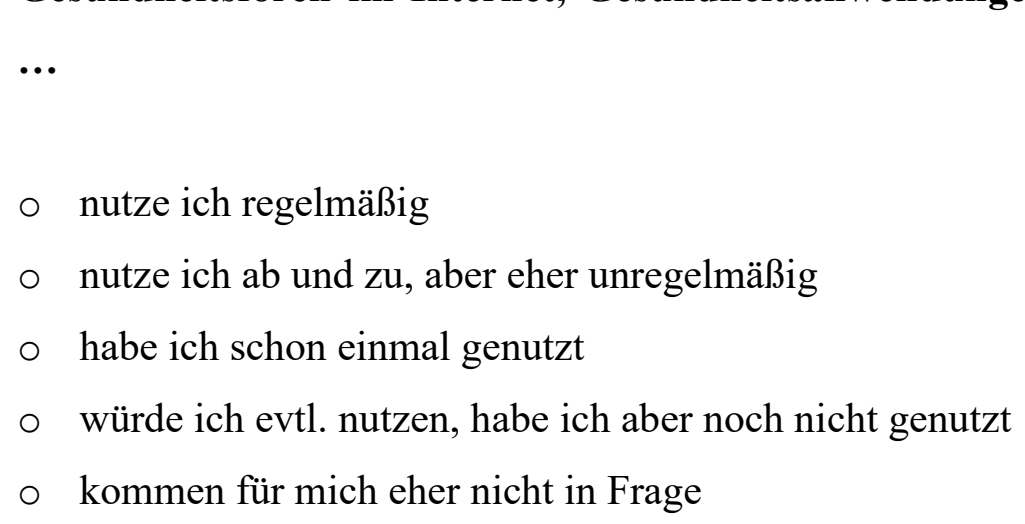

6. Bitte kreuzen Sie an, welche Angebote zu Gesundheitsthemen Sie schon einmal genutzt haben (Mehrfachantwort möglich)

- Informationen zu meiner Gesundheit im Internet suchen

○ Forum im Internet für Patienten/-innen

- Internetseite einer Selbsthilfegruppe

○ Video über ein Gesundheitsthema im Internet (z.B. über Youtube)

- Blog zum Thema Gesundheit

○ Online-Lexikon mit Fachbegriffen aus der Medizin

○ Interaktiver Kurs im Internet, z.B. mit spielerischen Elementen und Interaktionen mit anderen Betroffenen

○ Vereinbarung von ärztlichen Terminen über das Internet

○ Suche nach Spezialisten/-innen für meine Erkrankung im Internet

○ Herunterladen von Broschüren mit Gesundheitsinformationen aus dem Internet

○ E-Mail-Anfrage an meine/n Arzt/-in zu einem Gesundheitsthema

- App auf dem Smartphone

○ Fitnessarmband oder Smartwatch zu Gesundheitszwecken, ggf. mit dazugehöriger App

○-Book zu Gesundheitsthemen 
Im Folgenden finden Sie einige Aussagesätze. Bitte lesen Sie sie sich jeweils durch und bewerten, inwiefern Sie persönlich diesen Aussagen zustimmen.

Bitte kreuzen oder kreisen Sie Ihre Einschätzung jeweils in der Zahlenfolge von 1 bis 10 an.

Beispiel:

\begin{tabular}{|c|c|c|c|c|c|c|c|c|}
\hline \multicolumn{9}{|c|}{ Ich stimme überhaupt nicht zu........................... Ich stimme voll und gan } \\
\hline 1 & 2 & 3 & 5 & 6 & 7 & 8 & 9 & 10 \\
\hline
\end{tabular}

Oder

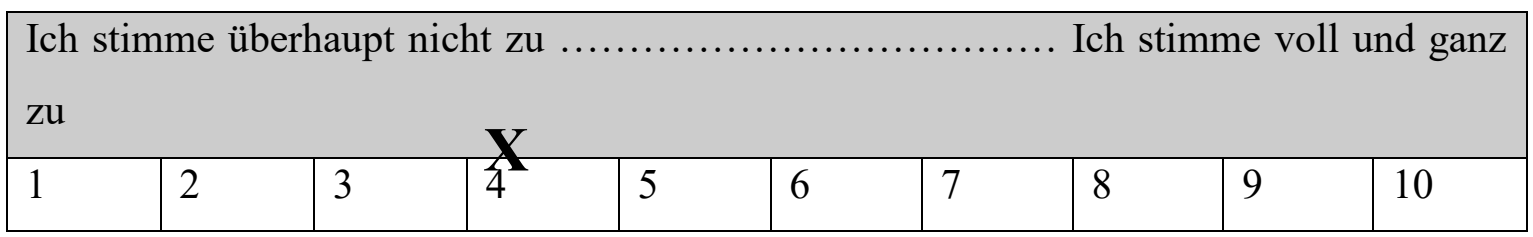

Wenn Sie bislang noch keine Internetangebote $\mathrm{zu}$ Gesundheitsdiensten genutzt haben, kreuzen Sie bitte jeweils unter den Fragen 7 bis 12 die folgende Antwortalternative an:

X Ich habe noch keine Internetangebote zu Gesundheitsthemen genutzt.

7. Internetangebote zu Gesundheitsthemen, die ich schon genutzt habe, habe ich im Allgemeinen gut verstanden.

\begin{tabular}{|c|c|c|c|c|c|c|c|c|c|}
\hline $\begin{array}{l}\text { Icl } \\
\mathrm{zu}\end{array}$ & Ime & $\mathrm{au}$ & ht $\mathrm{z}$ & & & & Ich & ne & nd $g$ \\
\hline 1 & 2 & 3 & 4 & 5 & 6 & 7 & 8 & 9 & 10 \\
\hline
\end{tabular}

○ Ich habe noch keine Internetangebote zu Gesundheitsthemen genutzt.

8. Ich weiß, wo ich Internet passende Angebote finden kann, die mir bei meinen Gesundheitsfragen helfen können.

$\begin{aligned} & \text { Ich stimme überhaupt nicht } \mathrm{zu} \ldots \ldots \ldots \ldots \ldots \ldots \ldots \ldots \ldots . \ldots \\
& \mathrm{zu}\end{aligned}$
\begin{tabular}{|l|l|l|l|l|l|l|l|l|l|}
\hline 1 & 2 & 3 & 4 & 5 & 6 & 7 & 8 & 9 & 10 \\
\hline
\end{tabular}

$\circ$ Ich habe noch keine Internetangebote zu Gesundheitsthemen genutzt. 
9. Ich fühle mich sicher, wenn ich Entscheidungen zu meiner Gesundheit (z.B. Therapieentscheidungen) auf der Basis von Gesundheitsinformationen aus dem Internet treffen muss.

\begin{tabular}{|c|c|c|c|c|c|c|c|c|c|}
\hline Ic & $\mathrm{me}$ & $\mathrm{au}$ & at $z$ & & & & & ne & nd \& \\
\hline 1 & 2 & 3 & 4 & 5 & 6 & 7 & 8 & 9 & 10 \\
\hline
\end{tabular}

$\circ$ Ich habe noch keine Internetangebote zu Gesundheitsthemen genutzt.

10. Internetangebote zu Gesundheitsthemen, die ich schon genutzt habe, haben mir bei gesundheitsbezogenen Entscheidungen geholfen (z.B. bei Therapieentscheidungen).

\begin{tabular}{|c|c|c|c|c|c|c|c|c|c|}
\hline \multirow[b]{2}{*}{1} & Ime & lau & ht & & & & & 6 & nd \\
\hline & 2 & 3 & 4 & 5 & 6 & 7 & 8 & 9 & 10 \\
\hline
\end{tabular}

○ Ich habe noch keine Internetangebote zu Gesundheitsthemen genutzt.

11. Bei der Nutzung von Gesundheitsinformationen aus dem Internet weiß ich sicher, ob diese Informationen aus zuverlässigen oder unzuverlässigen Quellen stammen.

\begin{tabular}{|c|c|c|c|c|c|c|c|c|c|}
\hline & ime & $\overline{\mathrm{au}}$ & at 2 & & & & Ich & ne & nd \\
\hline 1 & 2 & 3 & 4 & 5 & 6 & 7 & 8 & 9 & 10 \\
\hline
\end{tabular}

$\circ$ Ich habe noch keine Internetangebote zu Gesundheitsthemen genutzt. 
12. Internetangebote zu Gesundheitsthemen, die ich schon genutzt habe, haben mein medizinisches Wissen erhöht.

\begin{tabular}{|c|c|c|c|c|c|c|c|c|c|}
\hline & Ime & Iau & ht & $\ldots$ & $\ldots$ & $\ldots$ & $\mathrm{Icl}$ & ne & $\mathrm{dd}$ \\
\hline 1 & 2 & 3 & 4 & 5 & 6 & 7 & 8 & 9 & 10 \\
\hline
\end{tabular}

$\circ$ Ich habe noch keine Internetangebote zu Gesundheitsthemen genutzt.

Selbst wenn Sie noch nie eine mobile Anwendung (App) genutzt haben: Stellen Sie sich bei den beiden folgenden Fragen bitte vor, Sie wollten eine mobile Anwendung (App) für ein Smartphone oder ein Tablet PC nutzen, die Ihnen bei Ihrer Gesundheit helfen könnte.

Lesen Sie sich bitte die beiden Aussagesätze durch und schätzen ein, inwieweit Sie ihnen jeweils zustimmen. Kreuzen oder kreisen Sie Ihre Antwort bitte ein.

13. Ich weiß, wie ich passende Apps finden kann, die mir bei meiner Gesundheit helfen können.

Ich stimme überhaupt nicht $z u \ldots \ldots \ldots \ldots \ldots \ldots \ldots \ldots \ldots \ldots \ldots$. Ich stimme voll und ganz zu

\begin{tabular}{|l|l|l|l|l|l|l|l|l|l|}
\hline 1 & 2 & 3 & 4 & 5 & 6 & 7 & 8 & 9 & 10 \\
\hline
\end{tabular}

14. Ich weiß, wie ich Apps auf einem Smartphone oder Tablet nutzen kann, um mir bei meiner Gesundheit zu helfen.

\begin{tabular}{|c|c|c|c|c|c|c|c|c|c|}
\hline \multirow[b]{2}{*}{1} & \multirow{2}{*}{$\begin{array}{l}\text { ame } \\
2 \\
\end{array}$} & \multicolumn{2}{|c|}{ laupt nicht zu } & & \multicolumn{2}{|c|}{ n........... } & \multicolumn{2}{|c|}{ h stimme voll } \\
\hline & & 3 & 4 & 5 & 6 & 7 & 8 & 9 & 10 \\
\hline
\end{tabular}


15. Wie häufig benötigen Sie die Hilfe anderer Personen beim Lesen von medizinischen Anweisungen, Broschüren oder anderem schriftlichem Material, das Sie von Ihrem/r Arzt/Ärztin oder Apotheker/in bekommen haben?

$\circ$ nie

○ selten

○ manchmal

$\circ$ oft

○ immer

16. Wie oft haben Sie schätzungsweise im letzten Monat andere Personen (z.B. medizinische Fachkräfte, Angehörige, Bekannte) etwas bezüglich Ihrer Gesundheit gefragt oder eine andere Informationsquelle (z.B. Bücher, Internet) genutzt, um Fragen zu Ihrer Gesundheit zu beantworten?
○ nie
○ 1-4 mal
○ 5-9 mal
○ 10-14 mal
- 15 mal oder öfter 
17 Bitte beantworten Sie noch unsere Fragen zur Ihrer Zufriedenheit mit dem heutigen Vortrag:

17a. Hat Ihnen der Vortrag neue Erkenntnisse gebracht?

$\square$ Ja $\quad \square$ Nein $\quad \square$ Ich weiß nicht.

17b. Fühlen Sie sich über das Thema „Komplementärmedizin“ jetzt besser informiert?

$\square \mathrm{Ja} \quad \square$ Nein $\quad \square$ Ich weiß nicht.

17c. Fühlen Sie sich jetzt sicherer im Umgang mit dem Thema "Komplementärmedizin"?

$\square$ Ja $\quad \square$ Nein $\quad \square$ Ich weiß nicht.

17d. War der Vortrag für Sie verständlich und nachvollziehbar?

$\square \mathrm{Ja}$

$\square$ Nein

Ich weiß nicht.

17e. Wie bewerten Sie den Vortrag insgesamt?

$\square$ Sehr gut $\quad \square$ Gut $\quad \square$ Teils-teils $\quad \square$ Schlecht $\quad \square$ Sehr schlecht $\quad \square$ Ich weiß nicht

17f. Würden Sie den Vortrag weiterempfehlen?

$\square \mathrm{Ja} \quad \square$ Nein $\quad \square$ Ich weiß nicht.

$\begin{array}{lllll}\text { Vielen } & \text { Dank } & \text { für } & \text { Thre }\end{array}$ 


\subsection{Ehrenwörtliche Erklärung}

Hiermit erkläre ich, dass mir die Promotionsordnung der Medizinischen Fakultät der Friedrich-Schiller-Universität bekannt ist,

ich die Dissertation selbst angefertigt habe und alle von mir benutzten Hilfsmittel, persönlichen Mitteilungen und Quellen in meiner Arbeit angegeben sind,

mich folgende Personen bei der Auswahl und Auswertung des Materials sowie bei der Herstellung des Manuskripts unterstützt haben: Frau Prof. Dr. med. Jutta Hübner,

die Hilfe eines Promotionsberaters nicht in Anspruch genommen wurde und dass Dritte weder unmittelbar noch mittelbar geldwerte Leistungen von mir für Arbeiten erhalten haben, die im Zusammenhang mit dem Inhalt der vorgelegten Dissertation stehen,

dass ich die Dissertation noch nicht als Prüfungsarbeit für eine staatliche oder andere wissenschaftliche Prüfung eingereicht habe und

dass ich die gleiche, eine in wesentlichen Teilen ähnliche oder eine andere Abhandlung nicht bei einer anderen Hochschule als Dissertation eingereicht habe.

Geisenfeld, 03.01.2019

Nikolaus Halwas 


\subsection{Danksagung}

Ich bedanke mich bei meiner Doktormutter, Prof. Dr. Jutta Hübner, für die herausragende Betreuung und Unterstützung, sowohl während der Erstellung der Publikation, als auch der Dissertation.

Besonderer Dank gilt meiner Familie: Meinen lieben Eltern, die mir das Medizinstudium ermöglicht haben und meinen Geschwistern, Olga und Julia, die immer an meiner Seite sind. Vielen Dank für die unermüdliche Unterstützung und Motivation während meines Studiums. 